\title{
Enhancing the English-speaking skills through ECRIF: A preliminary study
}

\section{Mejorando las habilidades de habla inglesa a través de ECRIF: un estudio preliminar}

1 Gabriela Alexandra Caiza Aucapiña https://orcid.org/0000-0003-4143-6911 Universidad Técnica de Ambato, Facultad de Ciencias de la Educación, Carrera de Pedagogía de los Idiomas Nacionales y Extranjeros. Ambato, Ecuador. gcaiza8554@uta.edu.ec

2 Xavier Sulca-Guale

(iD) https://orcid.org/0000-0001-9456-0313

Universidad Técnica de Ambato, Facultad de Ciencias de la Educación, Carrera de Pedagogía de los Idiomas Nacionales y Extranjeros. Ambato, Ecuador. manuelxsulcag@uta.edu.ec

3 Wilma Elizabeth Suárez Mosquera iD https://orcid.org/0000-0001-7762-838X Universidad Técnica de Ambato, Facultad de Ciencias de la Educación, Carrera de Pedagogía de los Idiomas Nacionales y Extranjeros. Ambato, Ecuador. wilmaesuarezm@uta.edu.ec

$4 \quad$ Florentino Galo Rizzo Chunga Universidad Técnica de Ambato, Facultad de Ciencias de la Educación, Carrera de Pedagogía de los Idiomas Nacionales y Extranjeros. Ambato, Ecuador. fg.rizzo@uta.edu.ec

Artículo de Investigación Científica y Tecnológica Enviado: 24/12/2021

Revisado: $29 / 12 / 2021$

Aceptado: $12 / 01 / 2022$

Publicado:08/03/2023

DOI: https://doi.org/10.33262/concienciadigital.v6i1.4.1987

CONCIENCIA DIGITAL, es una Revista Multidisciplinar, Trimestral, que se publicará en soporte electrónico tiene como misión contribuir a la formación de profesionales competentes con visión humanística y crítica que sean capaces de exponer sus resultados investigativos y científicos en la misma medida que se promueva mediante su intervención cambios positivos en la sociedad. https://concienciadigital.org

La revista es editada por la Editorial Ciencia Digital (Editorial de prestigio registrada en la Cámara Ecuatoriana 


Palabras
claves:
desarrollo,
destreza
hablada,
ECRIF,
estructura,
etapas,
planificación

\section{Keywords:}

development, ECRIF, framework, planning, stages,

\section{Resumen}

Introducción. La destreza hablada del inglés es una destreza productiva que requiere de mucha práctica y de estrategias creativas de tal manera que los estudiantes adquieran el lenguaje siguiendo etapas que les permitan hablarlo de forma espontánea y fluida. La estructura de ECRIF es el camino para atender este requerimiento. Objetivo. Analizar la forma en la que la estructura ECRIF facilita la planificación de actividades para desarrollar la destreza hablada. Metodología. Para alcanzar este objetivo, se tomó una muestra de 32 estudiantes, 18 varones y 14 mujeres de edades entre 12 a 14 años. Además, la investigación se desarrolló desde un enfoque cuantitativo con un diseño experimental y la investigación bibliográfica. Debido a la pandemia del Covid-19, el estudio se llevó a cabo en la modalidad en línea. Diez sesiones consecutivas fueron necesarias para la recolección de la información las cuales fueron dictadas a través de las aplicaciones Zoom y WhatsApp. Los instrumentos para la recolección de datos incluyeron una pre prueba, una post prueba y una rúbrica para la destreza hablada. Una vez aplicado el experimento y obtenidos los resultados de las pruebas se utilizó el software SPSS, la prueba de Wilcoxon y la prueba Shapiro-Wilk para el análisis de los datos y la validación de la hipótesis. Resultados. Al final del estudio se demostró que, la estructura ECRIF ciertamente facilita la planificación de actividades para el desarrollo de la destreza hablada en los adolescentes ya que brinda un apoyo al estudiante para que hable con precisión y espontaneidad. Conclusión. Los investigadores descubrieron que los estudiantes que participaron en el estudio demostraron una mejora significativa en su nivel de dominio de la destreza hablada ya que el modelo ECRIF facilita la planificación de actividades tanto de práctica controlada por el profesor como actividades iniciadas espontáneamente por los estudiantes.

\section{Abstract}

Introduction. The English-speaking skill is a productive skill that requires a lot of practice and the use of creative strategies; therefore, students learn the language following stages that allow them to speak it spontaneously and fluently. ECRIF (Encounter, Clarify, Remember, Internalize and Fluency) is the way to achieve this goal. Objective. Analyze how ECRIF Framework facilitates the planning 
speaking skill. of activities to develop the speaking skill. Methodology. To accomplish the purpose of the study, the researchers took a sample of 32 students, 18 males and 14 females whose ages range from 12 to 14 . The research was conducted under a quantitative approached using an experimental design and a document analysis technique which was developed online due to the COVID-19 pandemic. Furthermore, ten consecutive sessions, which were conducted through the Zoom App and WhatsApp, were necessary to collect data. The instruments used in the study included a pretest, a posttest and a rubric for the speaking skill. After the treatment, and once the data was collected, the SPSS software, Wilcoxon test and ShapiroWilk test were used to analyze the data and validate the hypothesis.

Results. The obtained results showed that ECRIF Framework certainly facilitates the planning of activities to develop the speaking skill among teenagers because each stage offers clues and enough practice to speak with accuracy and spontaneity. Conclusion. The researchers found out that the students who participated in the study showed a significant improvement of the speaking proficiency level because ECRIF Framework facilitates the planning of activities which go from teacher-controlled to spontaneous student-initiated activities.

\section{Introduction}

The current research analyses the use of ECRIF Framework on the development of the speaking skill on students from Unidad Educative Gabriel Urbina. ECRIF offers the opportunity to deal with the problem of having a very low English-speaking level (see table 1) without affecting the students' reality by presenting a new planning design to practice the speaking skill in the classroom.

A reality that other methodologies cannot deal with, bearing in mind the results obtained by Patiung et al. (2015) who applied the communitive approach on a class and found out that despite learners were active and creative during the lessons, the teacher spent most of the time on presenting the content while students listened to the teacher, instead of practicing the skill with the target language.

Moreover Mohtar et al. (2015) conducted a case study to analyze the teacher's pedagogical practices and challenges, the pupils' views toward learning English and the activities used to promote the speaking skill. The findings revealed that the teacher used three main stages: introduction, engagement activity and practice; however, the teacher 
did not follow a direct theory or strategy to develop the speaking skill among young learners. Students showed interest in learning English, but the environment outside did not encourage them to use it a lot. Finally, the main challenges faced by the teacher were introducing the topic of each lesson, the modules photocopies, and the code switch to L1 to clarify instructions and concepts.

According to Khalaf (2016), ECRIF allows learners to experiment with the content by themselves becoming more autonomous and independent. Therefore, students work under a learner-centered approach where they can interact with other classmates, manage activities and materials by their own, focus on target language, and move toward objectives.

Improving the speaking skill of these students is of outmost importance because the area where they live is surrounded by tourist attractions and most students have parents who are owners of small tourist businesses. They are interested in growing up economically through tourism in their community. Consequently, these people are constantly implementing new ideas to receive foreigners from around the world. Therefore, being proficient at speaking English becomes a great advantage for them. This belief is supported by Tamrabet (2018) who determined that ECRIF enhances students' intercultural communicative competence.

In this context, this research work is important to develop mainly the learners' speaking skills that are needed for interaction with the international community, because "speaking is considered as the most essential skill when learning a foreign language because it is a basic ability for communication" (Alzahrani, 2019, p.49). According to Paredes (2019), ECRIF is the most appropriate method for students in view of the fact it motivates them during the lesson, increases their class participation and therefore guarantees the achievement of the speaking objective of using English with confidence and spontaneity. ECRIF provides the confidence students need because it is a more practical and dynamic method. Teachers play a different role as they mainly monitor the process and guide the activities meanwhile the students are the entire protagonist of their learning (Baque \& Paredes, 2020). Thus, students are active learners who liked to work cooperatively by using this method.

Furthermore Mezied (2017) and AlSaleem (2018), state that ECRIF shows a positive impact on students as it is a great strategy to teach vocabulary and improve memory retention which is particularly necessary when speaking a language. Finally important, Eker (2020) points out that ECRIF has a taxonomic structure like Blooms taxonomy where each stage pursues a hierarchical model where the learning objective is classified into levels of complexity and specificity. Some studies also demonstrate that ECRIF is the most suitable framework for teachers to work as basis in an active systematic reflection through the collection of concrete evidence for success or failure of the lessons. 


\section{Methodology}

A document analysis technique and experimental research were used to conduct this study. Firstly, a document analysis technique was used considering that the English teacher under study does not use any type of planning design and it is essential to explore if other English teachers use any type of planning to develop the speaking skill. According to Bowen (2009), a document analysis is a form of qualitative research in which documents are interpreted by the researcher to give voice and meaning around an assessment topic. Thus, the researchers had to measure the variables as they naturally occur and maintain the characteristic of the heterogeneous groups (Price et al., 2017). Moreover, the activities used in the eight lesson plans were based on the stages of ECRIF Framework with scientific support. For the encounter and clarify stages: YouTube videos were used because they direct students 'attention and scaffold reasoning (Al Jawad, 2020); comparing meanings, produce conscious attention to bits of target language; and choose the best response, helps to notice how grammar is used contexts (Jones \& Lock, 2010). For the remember and internalize stages: the researcher used think-pair-share because these activities allowed students to work enthusiastically into a cooperative environment while they had opportunities to remember and interact in the target language (Raba, 2017); and communicative games, in view of the fact students equally practice the vocabulary while they observe, take more risks and produces the target language in various ways (Dewi et al., 2017). For the fluently use stage: discussions, foster critical thinking, make conclusions spontaneously and allow students to express themselves in politely; and simulations, make students bring items to the class to create a realistic environment while interacting with others (Jabbarova, 2020).

\section{Population or Sample}

The participants in this study were a total of 32 students that was comprised of 18 males and 14 females age ranges 12 to 14 . They were students from eight, ninth and tenth years of basic education from Unidad Educative "Gabriel Urbina". It is important to mention that only these students were part of this research since they had access to the Zoom app. They live in different neighborhoods around Emilio María Terán village in Pillaro. They were heterogeneous students (dynamic, quiet, analytic, introverted /extroverted) who have been studying English for about four years. Moreover, the researchers were part of the population and their perspectives toward the type of planning design is essential to make up the final conclusions. Students were taken randomly and divided in two groups: the control group and the experimental group. The experimental group was taught under the ECRIF model for a total of eight sessions and using the oral module. At the end of the study, it was concluded that learners need to practice the target language instructions to be aware of their differences or the similarities between one's own culture and the new culture and the ECRIF model is particularly useful for those contexts. 


\section{Data Collection}

At first, data collection was planned to be done face to face; however, due to the global pandemic Covid-19 the researcher had to make some changes to conduct the study. First, the researcher conducted a round table discussion with the students from 8th, 9th and 10th year in the classroom to explore the interest and difficulties about the speaking skill. Moreover, the researcher prepared 10 sessions in zoom to measure the variables. In the first session, a pretest was applied and consisted of two parts: part number 1 where students had to interact with the teacher and answer basic information about themselves. Part number 2 required students to create a simple conversation with a partner using a picture prompt of two selected questions. After that, eight continuous lesson plans were applied based on the ECRIF Framework stages where students interacted individually, in pairs and groups. At the beginning of the lesson, the students encountered the new vocabulary using activities, such as watching YouTube videos and participating in a simple discussion guided by the teacher for 10 minutes. Then the students were involved in comparing meanings and choosing the best answer in Quizlet or Kahoot for 10 minutes. Later, the students remembered and internalized the vocabulary learned either in pairs or groups using questioning, think-pair-share, games and/or information gap-activities for about 20 minutes. In the last stage, students freely interacted with the whole class or in groups using either simulations, 4/3/2, or describing activities for about 20 minutes. The last day, the posttest was applied and contained the same questions and structure of the pretest. It was taken in pairs and with the aid of the Zoom app.

\section{Data Processing and Analysis}

Once the quantitative data was collected, it was analyzed through SPSS (Statistical Package for the Social Sciences), a statistics software to obtain fast and valid results of the data. To validate the hypothesis, related samples of each criterion in the rubric and the total score were used. The three evaluation criteria were qualitative data; therefore, "nonparametric" test was applied, the Wilcoxon test. Finally, to verify the significant differences between the pretest and the posttest, a Shapiro-Wilk test was necessary to use due to the sample being less than 50 to test the normality of the data series and to validate the alternative hypothesis or reject it and accept the null hypothesis.

\section{Results}

The results obtained in the field work are presented in the form of comparative analysis, in which the qualifications achieved by the elements of the sample are contrasted. This analysis was carried out, first, with each criterion of the rubric chosen for the evaluation, to later establish the differences in the results of the final grade. 
Table 1

Results of the pretest

\begin{tabular}{|l|l|c|}
\hline \multicolumn{2}{|l|}{} & Statistical \\
\hline Mean & 4,4688 \\
\hline $95 \%$ confidence Interval for the mean| & Lower limit & 3,6196 \\
& Upper limit & 5,3179 \\
\hline Median & 4,5000 \\
Minimum & 0,00 \\
\hline Maximum & 9,00 \\
\hline Range & 9,00 \\
\hline Asymmetry & $-0,053$ \\
\hline
\end{tabular}

Source: Research group

Descriptive statistics show that the teenager's English-speaking skills, in the pretest, have a mean of 4.47 and a median of 4.5. This can vary from 3.62 to 5.32. The minimum score achieved is 0 , while the maximum is 9 . Finally, there is a slight asymmetry of -0.053 to the left; This means that most students obtained a higher-than-average rating.

Table 2

Results of the posttest

\begin{tabular}{|l|l|c|}
\hline \multicolumn{2}{|l|}{} & Statistical \\
\hline Mean & 5,7500 \\
\hline 95\% confidence Interval for the mean & Lower limit & 5,1222 \\
& Upper limit & 6,3778 \\
& & \\
\hline Median & 6,0000 \\
Minimum & 2,00 \\
\hline Maximum & 9,00 \\
Range & 7,00 \\
\hline Asymmetry & $-0,411$ \\
\hline
\end{tabular}

Source: Research group

The descriptive statistics show that the teenager's English language speaking skills, in the posttest, have a mean of 5.75 and a median of 6.00. This can vary from 5.12 to 6.38 . The minimum score achieved is 2 , while the maximum is 9 . Finally, there is a slight 
asymmetry of -0.411 to the left; This means that most students obtained a higher-thanaverage rating.

\section{Validation of the hypothesis}

The research hypothesis was verified by comparing the related samples of each criterion in the rubric and the total score.

\section{Table 3}

Validation of the hypothesis

\begin{tabular}{|l|c|c|c|}
\hline & $\begin{array}{c}\text { Posttest - Grammar and } \\
\text { vocabulary - Pretest - } \\
\text { Grammar and vocabulary }\end{array}$ & $\begin{array}{c}\text { Posttest - } \\
\text { Fluency - } \\
\text { Pretest - } \\
\text { Fluency }\end{array}$ & $\begin{array}{c}\text { Posttest - Interactive } \\
\text { Communication - Pretest - } \\
\text { Interactive Communication }\end{array}$ \\
\hline Z & $-3,116$ & $-3,051$ & $-3,087$ \\
\hline $\begin{array}{l}\text { Sig. } \\
\text { asymptotic(bilateral) }\end{array}$ & 0,002 & 0,002 & 0,002 \\
\hline
\end{tabular}

Source: Research group

The test values are less than 0.05 in the three comparisons made, i.e., the null hypothesis is rejected in all cases; this indicates that there are significant differences between the pre and posttest of grammar and vocabulary, fluency and interactive communication. Therefore, considering the results given in the descriptive statistics, it can be affirmed that the ECRIF framework improves the use of grammar and vocabulary, fluency and interactive communication at speaking the English language.

Finally, to verify the significant differences between the pretest and the posttest, of the total scores of the evaluation of the skills for speaking the English language; it is necessary to test the normality of the data series, to determine the use of parametric or non-parametric statistical tests for the validation of the hypothesis.

As the sample was less than 50, the Shapiro-Wilk test was applied, the results of which are presented below:

\section{Table 4}

Shapiro-Wilk test results

\begin{tabular}{|c|c|c|c|}
\hline \multirow{2}{*}{ Pretest } & Statistical & gl & Sig. \\
\cline { 2 - 4 } & 0,944 & 32 & 0,097 \\
\hline \multirow{2}{*}{ Posttest } & Statistical & gl & Sig. \\
\cline { 2 - 4 } & 0,951 & 32 & 0,156 \\
\hline
\end{tabular}

Source: Research group 
The test values (sig.) are greater than 0.05 for the two data series. This means that both the pretest and posttest samples are normal; therefore, it is necessary to apply the $\mathrm{Z}$ test for the comparison of the related samples.

Table 5

Summary of hypothesis verification

\begin{tabular}{|c|c|c|c|}
\hline & Z & gl & $\begin{array}{c}\text { Sig. } \\
\text { (bilateral) }\end{array}$ \\
\hline $\begin{array}{c}\text { Pretest - } \\
\text { Posttest }\end{array}$ & $-6,051$ & 31 & 0,000 \\
\hline
\end{tabular}

Source: Research group

The test value lower than 0.05 rejects the null hypothesis, therefore, there are significant differences between the pretest and posttest means. Therefore, there is statistical evidence to affirm that the ECRIF framework improves the students's speaking skill.

\section{Conclusions}

- Students English speaking proficiency level was low as presented in the pretest. At the beginning of the experiment a pretest was applied. A rubric was used with the following criteria vocabulary and grammar, fluency and interactive communication. After a statistical analysis, the median in the pretest was 4.5 which represented a low score over 12. Furthermore, the results showed that vocabulary and grammar influence significatively towards the other skills because students need vocabulary and grammar to then speak fluently and have a comfortable interactive communication.

- The activities based on the ECRIF framework to teach the speaking skill depend on the stage teachers are working on. For instance, in the first stages of encountering and clarifying, teachers must plan activities that keep students' attention when receiving information such as: YouTube videos, pictures, comparing meanings and choosing the best response. Moreover, teachers must think about three characteristics in the remember and internalize stages: the activity should have connection with the language input, provide enough opportunities to practice (at least 6), and it should be done in cooperation with other learners. For instance, teachers should use think-pair-share, communicative games, information gap-activities and questioning. At the end, in the fluency use stage, teachers must choose activities that help students control the topic spontaneously and unconsciously, foster critical thinking and create a realistic environment. These activities may be 4/3/2 activity, discussions, simulations and describing activities either in pairs or small groups. 


\section{Bibliographical References}

Al Jawad, A. S. H. (2020). The Impact of Using YouTube Videos to Promote Students' Performance in Speaking Skill: A Case Study of a School in Libya. Journal of English Language Teaching and Applied Linguistics, 2(3), 38-46. https://alkindipublisher.com/index.php/jeltal/article/view/142

AlSaleem, B. I. A. (2018). The Effect of ECRIF Strategy on EFL Seventh Graders' Vocabulary Learning and Retention. Arab World English Journal, 9(2), 70-91. https://doi.org/10.24093/awej/vo19no2.5

Alzahrani, G. A. S. (2019). The Reasons behind the Weakness of Speaking English among English Department's Students at Najran University. Journal of Education and Human Development, $\quad 8(1), \quad 48-56$. https://jehdnet.com/journals/jehd/Vol_8_No_1_March_2019/7.pdf

Baque, T. A., \& Paredes, N. V. (2020). Applying ECRIF Method to Develop the Speaking Skill in the English Language. Red Investigación Santo Domingo. https://issuu.com/pucesd/docs/12419-2020-1tatiana_alejandra_baque_iza

Bowen, G. A. (2009). Document analysis as a qualitative research method. Qualitative Research Journal. https://www.emerald.com/insight/content/doi/10.3316/QRJ0902027/full/html

Dewi, R. S., Kultsum, U., \& Armadi, A. (2017). Using Communicative Games in Improving Students' Speaking Skills. English Language Teaching, 10(1), 63-71. https://eric.ed.gov/?id=EJ1124241

Eker, C. (2020). A New Taxonomy in Foreign Language Teaching: ECRIF. International Online Journal of Educational Sciences, 12(5). https://www.researchgate.net/publication/347774401_A_New_Taxonomy_in_Foreig n_Language_Teaching_ECRIF

Jabbarova, A. (2020). Modern Approaches in Teaching Speaking. Aрхив Hayчныхх Публикаций JSPI, 1-5

Jones, R., \& Lock, G. (2010). Functional grammar in the ESL classroom: Noticing, exploring and practicing. Retrieved from https://books.google.com.ec/books?id=tyKGDAAAQBAJ\&lpg=PP1\&ots=v1 -

$\mathrm{Nb} \_$Z8V\&dq=Jones\%2C\%20R.\%2C\%20\%26\%20Lock\%2C\%20G.\%20(2010).\%2 0Functional\%20grammar\%20in\%20the $\% 20$ ESL $\% 20$ classroom $\% 3 \mathrm{~A} \% 20$ Noticing $\% 2$ C\%20exploring\%20and\%20practicing.\%20Springer.\%20\%20\%20\%20\%20\&lr\&pg= PP1\#v=onepage\&q=Jones,\%20R.,\%20\&\%20Lock,\%20G.\%20(2010).\%20Functional 
\%20grammar\%20in\%20the\%20ESL\%20classroom:\%20Noticing,\%20exploring\%20 and $\% 20$ practicing. $\% 20$ Springer. $\& \mathrm{f}=$ false

Khalaf, R. (2016). The effect of learning-centered training on enhancing student-teachers' practice teaching skills at AUG. Dissertation Abstracts International, 6, 5623A. https://scholar.alaqsa.edu.ps/1993/

Mezied, S. K. M. (2017). The effectiveness of using ECRIF and PDP strategies in fifth graders' vocabulary learning and its retention. Arab World English Journal, 8(1), 6080. https://library.iugaza.edu.ps/thesis/12213.pdf

Mohtar, T. M. T., Abdullah, N. Y., \& Mat, M. (2015). Developing the speaking skill among ESL elementary learners. AJELP: Asian Journal of English Language and Pedagogy, 3, 161-180. https://ejournal.upsi.edu.my/index.php/AJELP/article/view/1226

Paredes, N. (2019). Comparing two methods for teaching productive skills of the English Language. Red Investigación Santo Domingo. http://redisd.org/index.php/es/resumenrecibidos-mt3/877-comparacion-de-dos-metodos-para-la-ensenanza-de-habilidadesproductivas-del-idioma-ingles

Patiung, D., Tolla, A., Anshari, A., \& Dolla, A. (2015). The study of learning speaking skills based on communicative approach. Journal of Language Teaching and Research, 6(5), 1093-1098. http://www.academypublication.com/ojs/index.php/jltr/article/view/jltr06051093109 8

Price, P., Jhangiani, R., Chiang, I., Leighton, D., \& Cuttler, C. (2017). Research methods in psychology. (3rd ed.) Washington, DC: Creative Common Attribution.

Raba, A. A. A. (2017). The influence of think-pair-share (TPS) on improving students' oral communication skills in EFL classrooms. Creative Education, 8(1), 12-23. https://www.scirp.org/journal/paperinformation.aspx?paperid=73454

Tamrabet, N. (2018). The Implementation of the ECRIF model in enhancing learners' intercultural communicative competence. Dissertation Abstracts International, 62,7742A. http://hdl.handle.net/123456789/3767

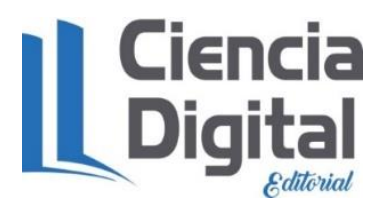


El artículo que se publica es de exclusiva responsabilidad de los autores y no necesariamente reflejan el pensamiento de la Revista Conciencia Digital.

\section{¿Ciencia}

El artículo queda en propiedad de la revista y, por tanto, su publicación parcial y/o total en otro medio tiene que ser autorizado por el director de la Revista Conciencia Digital.
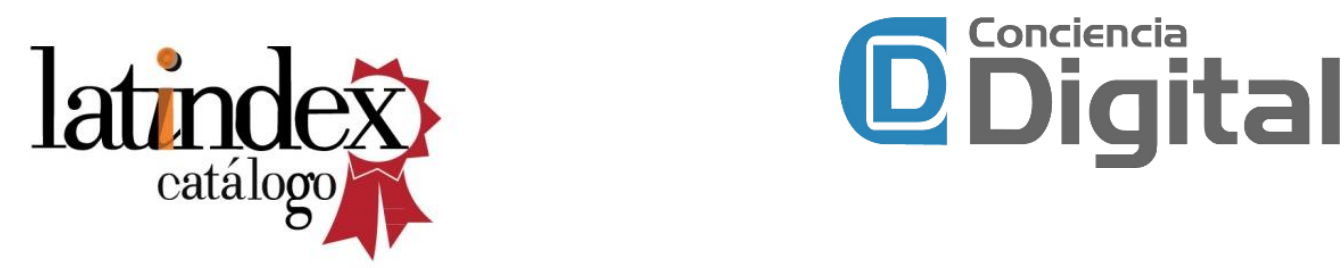

Indexaciones

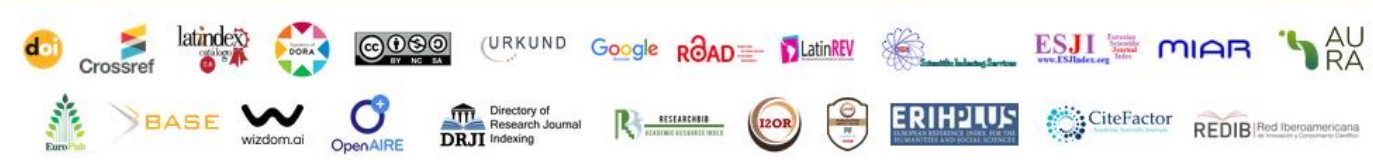

